\title{
Study and analysis of occupational risk factors for ergonomic design of construction worksystems
}

\author{
Ratri Parida $\mathrm{a}^{\mathrm{a},{ }^{*}}$ and Pradip Kumar Ray ${ }^{\mathrm{b}}$ \\ a, ${ }^{b}$ Department of Industrial Engineering and Management, Indian Institute of Technology Kharagpur, Kharagpur \\ 721302 , India
}

\begin{abstract}
Manual material handling $(\mathrm{MMH})$ is unavoidable because of the nature of jobs or tasks as and man-machine interfaces in a construction worksystem. Data were collected from six strata of workers viz., masons, mason helpers, carpenters, welders, gas cutters and ground-level helpers (259 out of 700 workers) from a construction site of a steel plant located in India to analyze different types of occupational risk factors, such as awkward posture, repetitive movements and others associated with MMH activities to assess their impact on musculoskeletal disorders (MSDs). It is essential that these risk factors are required to be under control through application of ergonomics-based design approaches for construction worksystem. In this context, multinomial logistic regression analyses were used to identify the significant risk factors among the workers. The results shows that masons, mason helpers, carpenters, welders/gas cutters and ground-level helpers are greatly affected by static body posture, type of tools used, excessive stress due to repetition, awkward postures and extreme climate, respectively. Appropriate preventive and corrective measures are suggested for minimization of risks associated with such jobs/tasks to improve health and performance of the workers.
\end{abstract}

Keywords: manual material handling; musculoskeletal disorders; sustainable change; man-machine interface

\section{Introduction}

Occupational risk has been defined as any condition of a job that can result in illness, injury, disability and death [1]. Although technology has advanced and new methods of work have been introduced, occupational risk factors are prevalent in every worksystem as workers perform diverse activities associating themselves with specific risk factors [2]. Traditional risk factors, such as repetition $[3,4,5,6]$, dynamic forces, awkward posture [7] and environmental factors, such as noise lighting and extreme temperature may be considered as occupational risk factors which may lead to work-related injuries and diseases, including musculoskeletal disorders (MSDs) workers. In this context, assessment of occupational risk factors associated with varieties of man-machine interface is a unique and critical research need for ergonomic design of industrial jobs.
Among various types of worksystems, construction is known for presenting a very high risk of musculoskeletal disorders (MSDs) to the workers as the workers are primarily engaged in a variety of manual material handling (MMH) activities, such as shovelling, welding, gas cutting and grinding of steel plates, chipping of concrete with the help of jack hammers, pulling and pushing of hand trolleys, repetitive lifting and laying of bricks at a heights, shuttering and deshuttering at construction sites and are exposed to several occupational risk factors, such as poor and awkward postures, repetitive movements, hand-arm vibration, heavy material handling, high physical work stress, overexertion, etc. in their routine jobs. Also, during construction work, the workplace keeps on changing and hence the workers become unfamiliar with the workplace which may further lead to MSDs and injuries [8]. It has been found that construction workers have two and a half times higher

\footnotetext{
*Ratri Parida. E-mail: ratriparida@gmail.com.
} 
trauma incidence than all other occupational groups, and a work-related injury rate of four times that of all other employed people [9]. Due to the high prevalence of hazards and typical nature of the construction sites, study of occupational risk factors has gained importance. Early identification and control of such factors in a construction worksystem may enhance safer environment and healthier workforce [7].

In this paper, details of the methodology pertaining to the assessment of present status of the construction worksystem with reference to varieties of physical and occupational hazards for various constructionrelated MMH activities are presented. Potential shortand long-term risks, MSDs for various segments of the human body, their causes, relationships between the risk factors and different kinds of injuries are identified and analyzed at a construction site of a steel plant located in eastern India. Appropriate engineering and administrative controls are suggested in respect of risks associated with a number of construction jobs from ergonomics perspective to improve health, safety and performance of the workers.

\section{Problem definition and research issues}

Construction industry has been considered as one of the hazardous industry in which fatal and non-fatal occupational injuries occur very frequently [10] due to its unique and multifaceted nature [11]. The overall injury rates among construction workers are higher which indicates that the occupational risk factors are dominant and may severely affect the workers resulting in severe injury consequences [12]. Mostly, workers complain about pains in their lower back, upper and lower extremities. The following problems based on data collection through a questionnaire-based survey of the construction site under study are worth mentioning:

(i) pains in back, shoulders and wrists (while carrying out shoveling activity continually for eight hours with additional overtime for 3 hours per day in many instances),

(ii) strain and sprain injuries (while unskilled ground-level workers carry large wooden planks, reinforcement bars, steel bolts, etc. that may have a weight of greater than $20 \mathrm{~kg}$ in each occasion), (iii) MSDs (skilled workers like fitters, etc. while tightening and bending the reinforcement bars and welders doing welding operations for long durations while weight of a typical welding pipe is about $31 \mathrm{~kg}$ ),

(iv) severe fatigue and loss of energy (due to exposure to adverse environmental conditions (heat stress) and workers working in an open environment), and

(v) improperly designed safety gadgets (causing inconvenience and discomfort to workers and may lead to accidents)

Many of these problems do arise because of highly repetitive and strenuous construction-related activities. In order to assess the impact of these problems on occupational risk, a questionnaire-based status survey of occupational risk factors in construction worksystem, highlighting a number of research issues, such as Characteristics of MMH Tasks (Issue-1), Features of the Working Environment (Issue-2), Types of MMH Activities (Issue-3), Characteristics of the Jobs/Tasks (Issue-4), Types of Tools and Equipment used (Issue-5), and Types of Occupational Health Problem including MSDs (Issue-6).

\section{Literature review}

Risk of occupational injuries may be associated with two major causes concerning the characteristics of work environment and practices and inherent and unique characteristics of the workers or individuals [13]. Thus, there may exist a causal relationship between the occupational risk factors and the prevalence of musculoskeletal disorders affecting different body parts [14]. Some of the important occupational risk factors, such as awkward posture, repetition, excessive force, hand-arm vibration (HAV) leading to increase in disorders and injuries of different body parts as identified may be discussed as follows:

(i) Awkward posture: Awkward posture may refer to significant deviation, such as static positioning, constrained body posture, etc. from the neutral body posture may be considered as an important risk factor $[15,16]$ Kneeling, Squatting, Flexion of trunk, twisted and bent trunk, twisted and bent neck, extension and flexion of 
neck are few awkward postures being associated with injuries and MSDs. Forward bending with lumbar flexion, pelvic tilting and restricted hip flexion may also increase tensile loads on the spine with the gradual development of low back pain $[17,18,19]$.

(ii) Repetition: A repetitive activity involves similar motion patterns for more than $50 \%$ of the work cycles. Cyclical work activities, repeated tasks that involve frequent and prolonged movement of body parts and joints such as wrist extension, ulnar deviation of wrist, etc. may be referred to as repetition [20]. Metal workers who perform repetitive and forceful wrist movements may have musculoskeletal and neurological problems because of nerve entrapment in the carpal tunnel [21].

(iii) Excessive Force: When there are forceful exertions, impact and impulsive loadings, the load exceeds the musculoskeletal strength at various joints and segments of the human body causing fatigue and injury $[20,22]$ Overexertion combined with lifting, bending and repetition [23] has been identified as one of the risk factor which reduces muscular force for carrying out the task [24, 25] and affects motor control and impairs accuracy of the movement [26].

(iv) Hand-arm vibration (HAV): The use of vibration-induced tools, such as jack hammers, grinders, chippers, etc. has been considered to be a significant factor for hand-arm vibration syndrome (HAVS). HAV affects vascular, neurological as well as musculoskeletal parts of the human body causing pain in upper limbs, muscle or Vibration-induced MSIs affects bone and joints of upper extremity. Exposure to vibration may alter proprioception and may cause workers use greater force to complete a task. Forceful exertions are considered to be one of the occupational risk factors causing injuries to soft tissues [20]. Workers who are exposed to HAV are most likely to have two times higher risk of CTS [27].

Since the condition of a typical construction worksystem may change over time, it becomes difficult to identify total set of the risk factors unless a large number of construction-related jobs, their characteristics and methods of working are closely observed and analyzed at a given construction worksite.

\section{Study methodology}

In order to study and analyze occupational risk factors for different kinds of construction-related activities, so as to enhance ergonomic design of worksystems, a systematic methodology consisting of a number of steps in sequence, such as (i) data collection, (ii) data analysis, (iii) results and discussions, and (iv) suggestions and improvement actions (remedial and preventive measures) is to be employed. The details of these steps are given below.

\subsection{Data collection}

\subsubsection{Selection of a construction site}

One of the pioneering steel companies located in eastern India has been chosen for data collection in view of enormous opportunities it offers in studying varieties of situations in construction involving MMH tasks. In this context, Linz-Donawitz \#3 \& Thin Slab Casting and Rolling (LD\#3 \& TSCR) construction site has been chosen out of nine major brown-field projects viz. Linz-Donawitz \#3 \& Thin Slab Casting and Rolling (stated briefly as LD\#3 \& TSCR), I- Blast Furnance (BF), Pellet plant, rail and road logistics, power distribution system for MPDS\#5, MPDS\#6, cable tunnel, and LDSS building, raw material handling $(\mathrm{RMH})$, battery $10 \& 11$ and by-product, CDO and fabrication yard. This project site is preferred over others because manual intervention is found to be comparatively high for this project. Data were collected from different facilities of the site, such as slag asile, charging asile, converter shop, torpedo pit, tunnel furnace, casting shop, secondary metallurgy and ladle preparation, rolling mill, etc. at the project site.

Although heavy and mechanized equipments, such as Kabelco cranes (with 550T/250T capacity), Manitowoc and AVG Fusion (80T), TFC-280 and Gottwald cranes (75T), tire-mounted Krupp cranes (40T), Hydra (8T/12T) and other mechanized equipment being are at LD3 \& TSCR construction site, MMH activities, such as lifting, carrying, pulling pushing, etc are very common at this site. It has been observed that the workers carry out the ground-level construction work starting from clearance of site, excavation, 
reinforcement/ shuttering work, anchoring, etc. to finishing and plastering of walls under several agencies lik M/S L\&T (civil and structural), M/S Tarapore, M/s Jusco (civil and structural), M/S Shapoorji, M/s Micco, M/S Power Max, M/s TPL, and $\mathrm{M} / \mathrm{S}$ Tata Blue Scope.

\subsubsection{Preliminary pilot survey}

As a systematic procedure is needed for collection of relevant data on several aspects of occupational risks of the jobs and activities selected, a phase-wise plan has been made for data collection. The phases are as follows:

1. Preliminary data collection (mainly primary

\begin{tabular}{|c|c|c|c|l|}
\hline \begin{tabular}{c} 
S1 \\
No \\
\hline 1
\end{tabular} & $\begin{array}{l}\text { Occupa- } \\
\text { tion }\end{array}$ & $\begin{array}{c}\text { Total } \\
\text { Number } \\
\text { of } \\
\text { Workers }\end{array}$ & $\begin{array}{c}\text { Number of } \\
\text { Workers } \\
\text { Interviewed/ } \\
\text { Surveyed }\end{array}$ & Jobs Involved \\
\hline 2 & $\begin{array}{c}\text { Mason } \\
\text { Helpers }\end{array}$ & 150 & 45 & $\begin{array}{l}\text { Bricklaying, plas- } \\
\text { tering, RCC work }\end{array}$ \\
\hline 3 & Carpenters & 200 & 63 & $\begin{array}{l}\text { Shovelling, RCC } \\
\text { work, pulling and } \\
\text { pushing of trolley, } \\
\text { etc. }\end{array}$ \\
\hline 4 & Welders & 50 & 20 & $\begin{array}{l}\text { Shuttering and de- } \\
\text { shuttering }\end{array}$ \\
\hline 5 & $\begin{array}{c}\text { Gas } \\
\text { Cutters }\end{array}$ & 50 & 15 & $\begin{array}{l}\text { Welding of steel } \\
\text { plates and struc- } \\
\text { tures }\end{array}$ \\
\hline 6 & $\begin{array}{c}\text { Ground- } \\
\text { level Hel- } \\
\text { pers }\end{array}$ & 50 & 30 & $\begin{array}{l}\text { Putting of steel } \\
\text { plates and rods }\end{array}$ \\
\hline & Total & 750 & 259 & $\begin{array}{l}\text { materials, material } \\
\text { shifting and lifting }\end{array}$ \\
\hline
\end{tabular}

data): Understanding of the worksystems (involving physical activities being carried out by concerned persons), and

2. Evaluation-related detailed data collection (primary as well as secondary data): For detailed analysis.

A number of visits to the construction sites were made for data collection through direct observations and interactions with concerned workers. The details of the data collected are as follows:

1. Preliminary data collection

(i) Types of on-going construction jobs (which may be segregated into civil, mechani$\mathrm{cal} / \mathrm{structural}$ and electrical),

(ii) Types of activities against a type of work, (iii) Types of tools, mechanical aids and other handling tools used in

(iv) Types of safety gadgets being used/ recommended for workers during work,

(v) Rules/regulations/standards as recommended and used for construction work,

(vi) List of problems as observed and reported, and

(vii) Work postures and body movements for different activities

These data were collected by several means, such as discussion with concerned persons, reference to past records and data, and direct observations.

\section{Evaluation-related detailed data collection}

The extent of severity of several occupational risk factors, (such as age and experience) on the health of the workers were observed directly. However, influencing factors and variables that cannot be measured directly were framed in terms of questions. A comprehensive and structured questionnaire is designed as required and the data pertaining to the analysis of the quantitative relationship between the risk factors and the types of injuries and MSDs have been collected.

The questionnaire as designed is divided into two parts. In first part (Part-I), 16 items related to the personal details of the workers including data pertaining to work conditions, kinds of jobs and contractual obligations, if any, are mentioned. The second part (Part-II) contains 125 questions of different types related to each research issue as considered.

Workers were selected randomly from the total population and grouped into a number of occupations (strata) based on the similarities in the nature of the jobs, such as masons, carpenters, mason helpers, welders, gas cutters and helpers using stratified sampling technique. Division of sample into a number of strata results into smaller sample size for each stratum as given in Table 1 .

\subsection{Data analysis}

In this study, multinomial logistic regression is used for the analysis of occupational risk factors. Multinomial logistic regression requires the response variable to be polynotomous in nature and a set of predictor variables either continuous or categorical or combined in nature, to predict the response variable. The analyses were done for assessing occupational 
risk factors as given in Table 2. The results from the analyses are presented in the following section.

\section{Table 1: Details of the sample collected}

\subsection{Results and discussion}

This study shows that occupational risks are highly correlated with work-related risk factors that may cause injuries and subsequent MSDs of various body segments and joints.

As has been observed, masons are highly prone to neck, shoulder and back pain in $80 \%, 66 \%$ and $64 \%$ of the persons interviewed respectively because of a number of risk factors, such as age, experience, heavy workload and physical tiredness. Other significant risk factors are static posture, prolonged sitting, repetitive work, awkward posture, strenuous tasks, squatting and standing. Mason helpers consist of $62 \%$ male and $38 \%$ female out of total workers interviewed. Mason helpers (both male and female) mostly feel pain in their wrists $(53.2 \%)$ (because of long working hours and stature), shoulder (32.3\%) (because of physical tiredness, long working hours, method of work and excessive stress), elbows $(27.4 \%)$ (because of climate and stress) and back $(66.1 \%)$ (because of types of tools used, methods of work, lack of rest, repetitive work and strenuous task). Pain in wrists, elbows and shoulders are found to very common for carpenters due to the use of hand tools, excessive stress (64\% of the carpenters), climate and environment and physical tiredness or stress ( $94 \%$ of the carpenters) which are found to be highly significant. Occupational risk factors, such as repetitive stress, static and awkward postures along with prolonged sitting and standing significantly contribute to risks of dry eyes, flash injuries, severe back and shoulder pain among welders and gas cutters. Ground-level helpers have pain in their wrists, elbows, neck and back due to excessive workload, extreme climate and heat stress. As far as masons are concerned, static posture and prolonged sitting are significant risk factors. Risk factors for mason helpers are tool used, long working hours, lack of rest, repetitive and strenuous task. For carpenters, the most critical risk is excessive stress. Welders and gas cutters are affected by awkward posture, while extreme climate affects ground-level workers.

Evaluation of these risk factors may be carried out through biomechanical, physiological and physical analysis. Age, stature, tools and equipment, methods of work, awkward postures, frequent bending and twisting are related to biomechanical evaluation while physical tiredness, methods of work, lack of rest and strenuous tasks are needed to be evaluated physiologically so that the tasks or jobs are within the physiological capability of the workers. Similarly, excessive physical stress, heat stress and climate/environment are required to be considered for physical evaluation. Since, majority of the risk factors are required to be addressed through biomechanical evaluation, it is essential that biomechanical evaluation of all these jobs as mentioned needs to be initiated as a priority basis so that the prevailing problems of MSDs among the workers can be addressed and preventive and remedial measures are identified and implemented. 
Table 2: List of Occupational Risk Factors

\begin{tabular}{|c|c|c|c|}
\hline Occupation & Risk Factors & $\begin{array}{l}\text { Critical Body Movements } \\
\text { and Activities }\end{array}$ & Associated Jobs \\
\hline Mason & $\begin{array}{l}\text { Age, experience, workload, } \\
\text { climate, physical tiredness, } \\
\text { long working hours, repetitive } \\
\text { work, static posture, pro- } \\
\text { longed sitting, awkward pos- } \\
\text { ture, strenuous job }\end{array}$ & $\begin{array}{l}\text { Squatting, standing, climbing, reaching } \\
\text { overhead, lifting, lowering }\end{array}$ & $\begin{array}{l}\text { Lifting of H-beams, } \\
\text { wooden planks, shutter- } \\
\text { ing and de-shuttering }\end{array}$ \\
\hline $\begin{array}{l}\text { Mason } \\
\text { Helpers }\end{array}$ & $\begin{array}{l}\text { Long working hours, stature, } \\
\text { night shift, physical tired- } \\
\text { ness at end of shift, method of } \\
\text { work, excessive workload, } \\
\text { repetitive task, awkward } \\
\text { posture, tool, repetitive work, } \\
\text { climate, stress }\end{array}$ & $\begin{array}{l}\text { Grasping, shovelling, placing, standing, } \\
\text { twisting, walking, kneeling, suddenly } \\
\text { changing position, walking, stooping and } \\
\text { sieving }\end{array}$ & $\begin{array}{l}\text { Mixing of sand and } \\
\text { cement, lifting and } \\
\text { carrying of bricks, siev- } \\
\text { ing of sand, transferring } \\
\text { mortar to masons on } \\
\text { scaffolds and house- } \\
\text { keeping }\end{array}$ \\
\hline Carpenters & $\begin{array}{l}\text { Awkward posture, static } \\
\text { posture, physical tiredness at } \\
\text { end of shift, extreme climate, } \\
\text { excessive workload, strenu- } \\
\text { ous task, }\end{array}$ & $\begin{array}{l}\text { Lifting, lowering, placing, reaching } \\
\text { overhead, combination of all activities, } \\
\text { squatting, standing and kneeling }\end{array}$ & $\begin{array}{l}\text { Cutting of boards, fixa- } \\
\text { tion of H-beams, } \\
\text { wooden planks, shutter- } \\
\text { ing and de-shuttering } \\
\text { while erecting beams } \\
\text { and columns }\end{array}$ \\
\hline Welders & $\begin{array}{l}\text { Repetitive work, lack of rest, } \\
\text { awkward postures, static } \\
\text { postures, prolonged sitting } \\
\text { and standing }\end{array}$ & $\begin{array}{l}\text { Holding/grasping, lifting, reaching over- } \\
\text { head, combination of all activities, bend- } \\
\text { ing or stooping, stretching and squatting }\end{array}$ & $\begin{array}{l}\text { Welding of steel plates } \\
\text { and beams }\end{array}$ \\
\hline Gas Cutters & $\begin{array}{l}\text { Repetitive work, lack of rest, } \\
\text { awkward postures, static } \\
\text { postures, prolonged sitting } \\
\text { and standing }\end{array}$ & $\begin{array}{l}\text { Holding/grasping, pulling, carrying, } \\
\text { reaching overhead, combination of ac- } \\
\text { tivities, bending or stooping, stretching } \\
\text { and squatting }\end{array}$ & $\begin{array}{l}\text { Gas cutting of steel } \\
\text { plates, beams, vessels }\end{array}$ \\
\hline Helpers & $\begin{array}{l}\text { Static posture, strenuous } \\
\text { tasks, heat stress, excessive } \\
\text { workload, repetitive work, } \\
\text { method of work, uneven work } \\
\text { surface }\end{array}$ & $\begin{array}{l}\text { Standing, stretching, walking, kneeling, } \\
\text { combination of all movements, climbing, } \\
\text { grasping, lifting, lowering, walking and } \\
\text { pulling }\end{array}$ & $\begin{array}{l}\text { Pulling rope to lift mate- } \\
\text { rials through rope pul- } \\
\text { ley, manually lifting and } \\
\text { shifting materials, such } \\
\text { as sheets( } 10 \text { to } 12 \mathrm{~kg} \\
\text { per sheet) and grills (3 } \\
\text { to } 4 \mathrm{~kg} \text { per grill) }\end{array}$ \\
\hline
\end{tabular}

\subsection{Suggestions and improvement actions \\ (Preventive and Corrective measures)}

It is found that appropriate preventive and corrective measures may be required in respect of risks associated with such jobs or tasks from ergonomic perspective. The following preventive measures are suggested: (i) for masons: sufficient space may be provided on the scaffolds so as to avoid static and awkward postures, (ii) for mason helpers: handle of the shovel may be redesigned and fibre-handled shovels may be replaced with wooden ones, (iii) for carpenters: in order to avoid repetitive movements, hand saws may be replaced with power saws, (iv) for welders and gas cutters: frequency of rest periods may be increased to allow the workers recover from excessive work stress, and (v) ground-level workers: job rotation and sufficient rest breaks may be pro- posed to overcome excessive stress because of climate/environment. However, remedial measures, such as wellness training and periodic medical checkup on regular basis need to be undertaken to minimize the effect of risk factors.

\section{Conclusions}

It is justified to assume that the issues considered in this study are relevant for evaluation of $\mathrm{MMH}$ tasks at similar kinds of worksystems with comparable types of technology and persons employed. The potential benefit of carrying such a study lies in developing appropriate guidelines for construction workers to secure sustainable change in the construction worksystems which may reduce the occupational hazards (particularly MSDs) to a large extent and improve health, safety and performance of workers under prevailing construction work environment in India. 


\section{References}

[1] Wilcock, Applied theories in occupational theory: a practical approach instructor's manual, (2008).

[2] Pinto, A., Nunes, I.L., Ribeiro, R. A., Occupational risk assessment in construction industry- overview and reflection, 49 , (2011), 616-624.

[3] Cox, T., Repetitive work: occupational stress and health. In Cooper, C.L. and Smith, M.J. (Eds.), Job Stress and bluecollar work, (1985), 85-112. New York: Wiley.

[4] Medsker, G.J. and Campion, M.A., Job and team design. In Salvendy, G. (Ed.), Handbook of Human Factors and Ergonomics ( $2^{\text {nd }}$ ed.), (1997), 450-489. New York: Wiley

[5] Salvendy, G. and Smith, M.J. (Eds.), Machine-pacing and occupational stress. (1981), London: Taylor and Francis.

[6] Carayon, P., Smith, M.J., Haims, M.C. (1999). Work organization, job stress, and work-related musculoskeletal disorders. Human Factors, 41(4), 644-663.

[7] Silverstein, B.A., Fine, L.J. and Armstrong, T.J. Occupational factors and CTS. American Journal of Industrial Medicine, 11, (1987), 343-358.

[8] Hsu, D.J. et al. , Effect of elevation change on work fatigue and physiological symptoms for high-rise building construction workers, Safety Science, 46, (2008), 833-843.

[9] Zwerling, C., Miller, E.R., Lynch, C.F., Tarner, J., Injuries among construction workers in rural lowa: emergency department surveillance, Journal of Occupational and Environmental Medicine, 38(7), (1996), 698-704

[10]Rigen, K., Seegal, J., Safety and health in construction industry, Annual review of public health, 16, (1995), 165-188.

[11]Denis, D., St-Vincent, M., Imbeau, D., Jette, C., Nastasia, I. Intervention practices in musculoskeletal disorders prevention: A critical literature review. Applied Ergonomics 39, (2008), $1-14$.

[12]Larsson, T.J. and Field, B., The distribution of occupational injury risks in the Victorian construction industries, Safety Science, 40, (2002), 439-456.

[13] Schneider, S. and Susi, P., Ergonomics and construction: A review of potential hazards in new construction. American Industrial Hygiene Association Journal 55(7), (1994), 635-649.

[14] Bernard, B. P. et al., Musculoskeletal Disorders and Workplace Factors: A Critical Review of Epidemiologic Evidence for Work-related Musculoskeletal Disorders of the Neck, Upper Extremity and Low Back.CDC/NIOSH , 97-141, (1997), (Cincinnati, OH:NIOSH).
[15] Chaffin, D.B., Andersson, G.B.J.,. Occupational Biomechanics. Wiley, New York, (1984), 451

[16] Putz-Anderson, V., Cumulative Trauma Dsiorders, 1988, Taylor and Francis, NY.

[17] Nordin, M., Frankel, V.H.,. Basic Biomechanics of the Skeletal System. Lippincott Williams \& Wilkins, Philadelphia,pp. (2001), 256-285.

[18] Esola, M.A., McClure, P.W., Fitzgerald, G.K., Siegler, S., 1996.Analysis oflumbar spine and hip motion during forward bendingin subjects with and without a history oflow back pain. Spine 21(1), 71-78.

[19] Porter, J.L., Wilkinson, A., Lumbar-hip flexion motion: acomparative study between asymptomatic and chronic low backpain in 18- to 36-year-old men. Spine 22 (13), (1997), 1508-1513.

[20] NIOSH, Musculoskeletal Disorders and Workplace Factors: A Critical Review of Epidemiologic Evidence for Work-

[21]related Musculoskeletal Disorders of the Neck, Upper Extremity, and Low Back. Publication No. 97-141, (1997), (Cincinnati: DHHS NIOSH).

[22] Sauni, R., Paakkonen, R., Virtema, P., Toppila, E., Uitti, J., Dose-response relationship between exposure to hand-arm vibration and health effects among metal workers. Ann. Occup. Hyg., 53(1), (2009), 55-62.

[23] Hales, T. R. and Bernard, B. P., Epidemiology of workrelated musculoskeletal disorders. Orthopedic Clinics of North America, 27, (1996), 679-709.

[24] Veddar, J., Carey, E., A multi-level systems approach for the development of tools, equipment and work processes for the construction industry. Applied Ergonomics 36, (2005), 471480 .

[25] Edwards, R., Human Muscle Function and Fatigue Human Muscle Fatigue. Physiological Mechanisms, London., (1981), 8.

[26] Gandevia, S.C., Spinal and supraspinal factors in hu man muscle fatigue. Physiological Reviews 81 (4), (2001), 1725 1789

[27] Missenard, O., Mottet, D., Perrey, S., The role of cocontraction in the impairment of movement accuracy with fatigue. Experimental Brain Research 185, (2008), 151-156.

[28] Palmer K, Harris C, Coggon D., Carpal tunnel syndrome and its relation to occupation: a systematic literature review. Occup Med; 57, (2007), 57-66. 